\title{
Solution For The Development Of Prisoners In Class III Gorontalo Women's Prison
}

\author{
Sumiyati Beddu1${ }^{*}$, Darmawati ${ }^{1}$ \\ 1 Faculty of Law, Universitas Ichsan Gorontalo, Indonesia \\ *Correspondence: sumiyatiumi677@gmail.com
}

ARTICLE HISTORY
Received: 24.11 .2021
Accepted: 21.12 .2021
Published: 27.12 .2021
ARTICLE LICENCE
Copyright $\odot 2021$ The
Author(s): This is an
open-access article
distributed under the
terms of the Creative
Commons Attribution
ShareAlike 4.0
International (CC BY-SA
4.0)

\begin{abstract}
The correctional facility is an implementing agency of the criminal system that has a function to foster citizens of correctional development, including in this case women undergoing an obligatory sentence to participate in a whole series of coaching activities in the correctional institution. This paper aims to look at the implementation of this form of guidance and find the right solution related to the problem of guiding prisoners in women's prisons, especially Class III Gorontalo prisons. The results obtained were that the implementation of the existing forms of guidance at the Class III Gorontalo Women's Prison was divided into three stages of coaching, namely the initial stage, the advanced stage and the final stage coaching. To overcome problems in the implementation of coaching women prisoners, synergy is needed between all parties involved, starting from prisoners, correctional officers and related agencies to cooperate with each other in the implementation of training for female prisoners. For this reason, it is necessary to repair and add infrastructure to support coaching activities and to involve officers in prisons through training activities that can support the implementation of coaching. Concerning the handicrafts of prisoners, it is also expected to increase marketing through the media, given the condition of Covid 19 which limits people from being able to interact directly with prisoners in prison
\end{abstract}

Keywords: Fostering; Women Prisoners; Correctional Institutions

\section{Introduction}

Penitentiary is a place for prisoners to undergo corporal punishment. In the criminal justice system, prisons function as a place to provide guidance to inmates so that after serving a period of punishment, correctional inmates can realize mistakes, do not repeat crimes that have been committed and can be accepted back in community life. Law must avoid the criminal.(Salam, 2019) The change of name from Prison to Correctional Institution is expected to achieve the goal of punishment which is integrated with the restoration of the unity of life (rehabilitation) and livelihood (reintegration) for the inmates.

Based on the provisions stipulated in Article 12 of Law Number 12 of 1995 concerning Corrections, it is stated that:

"In the context of fostering prisoners in prisons, classification is carried out on the basis of: age, gender, length of sentence imposed, type of crime and other criteria in accordance with the needs and development of development."

Prison development is a system. As a system, prisoner development has several components that are interrelated and work together to achieve a goal (Harsono, 1995). There are four important components in the implementation of prisoner development including: prisoners, families (people who are around prisoners), the community and correctional officers.

Prison development is always directed at resocialization (unification of relations with the community) with a correctional system based on Pancasila and the 1945 Constitution of the Republic of Indonesia UUD 1945 (Darmawati, 2019). 
The Class III Gorontalo Women's Correctional Institution is one of the prisons under the auspices of the Gorontalo Province Legal and Human Rights Regional Office which is tasked with carrying out guidance for female inmates in Gorontalo City. The implementation of coaching in prisons has been carried out in accordance with existing procedures, but in practice it is still often found inmates who commit violations in the prison. The existence of a form of violation that occurs makes what is expected from Law Number 12 of 1995 concerning Corrections has not been achieved as a whole.

The implementation of coaching in the Class III Gorontalo Women's Prison is carried out by involving all elements ranging from officers and coaches from the prison itself, prisoners and institutions and the community who in this case can contribute in terms of implementing coaching in prisons. Regarding the implementation of special guidance for female prisoners, there are no clear guidelines in Law Number 12 of 1995 concerning Corrections or in Government Regulation Number 31 of 1999 concerning Guidance and Guidance and Correctional Citizenship. Therefore, the implementation of coaching female prisoners in prisons is the same as coaching other prisoners.

The purpose of this paper is to look at the implementation of the form of coaching in the Class III Gorontalo Women's Prison and find the right solution related to the problem of coaching prisoners in the Women's Prison, especially the Class III Gorontalo Prison.

\section{Methodology}

This study uses a normative - empirical research method, which looks at the phenomena that occur in the field and relates it to legal norms related to the development of female prisoners. The research location is the Class III Women's Correctional Institution, Gorontalo. Sources of data are primary data obtained directly in the field and secondary data consisting of legal and statutory literature related to this research. The data obtained were processed and analyzed based on the problems raised to obtain a clear picture of the problems and solutions in terms of the implementation of development in the Class III Women's Prison Gorontalo

\section{Result and Discussion.}

\subsection{Implementation of the Form of Guidance in Class III Correctional Institutions Gorontalo}

The process of fostering prisoners begins when prisoners enter the correctional institution until they are released. In the implementation of guidance for female prisoners at the Class III Gorontalo Correctional Institution, it refers to Government Regulation Number 31 of 1999 concerning Guidance and Guidance of Correctional Citizens and also refers to the regulations of institutions or agencies in prisons.

The implementation of coaching at the Class III Gorontalo Women's Prison begins with the acceptance of prisoners. After the convict is accepted, it is then registered and the identity search is carried out on the inmate. From the results of identity searches, followed by the placement of prisoners in prisons based on observations made by Correctional Officers. The implementation of the development model at the Women's Special Penitentiary is the same as the coaching model in general. where this is regulated in Law Number 12 of 1995 concerning Corrections and followed up by Government Regulation Number 31 of 1999 concerning Guidance and Guidance of Correctional Citizens. If we look at what is the purpose of the implementation of coaching for prisoners is to educate the prisoners to become fully human, aware of their mistakes, correcting and not repeating their criminal acts again so that they can be accepted again in society. To achieve this goal, inmates must follow the entire series of coaching programs in the Class III Gorontalo Women's Prison.

The initial phase of guidance carried out by female inmates at the Class III Gorontalo Women's Prison was preceded by a one-month environmental observation and research phase. The female prisoners in prison were introduced to life in prison and explained what their rights and obligations were while serving their sentence in prison. This women is relate to gender norm.(Nur Dahniar, Safrin Salam, 2021) Based on the provisions of the Minimum Standard Rules (SMR) at point 35 it is stated that (Zulfa, 2014).

a. Every prisoner at the time of admission to the Correctional Institution must be provided with written information about the regulations governing the treatment of prisoners in his category, the disciplinary measures imposed by the prison, the permitted ways of seeking information and filing complaints, and other matters necessary to enable him to obtain information. understand, both their rights and obligations and to adapt to life in prison. 
b. If a prisoner and/or prisoner is illiterate, the above-mentioned information must be conveyed orally.

After going through the process of introducing the environment, then the prisoners begin to undergo early stage coaching through personality and independence development. The process of personality development is carried out through religious activities such as khatam Quran, as the results of the author's interview with one of the female inmates, Initial S (48 years old) stated that we follow the entire series of coaching in prisons, because it is not only useful for myself, but it makes me even better. For example, the activity of completing the Quran. Obstacles obtained in the implementation of religious development activities are the lack of supporting facilities in terms of the implementation of coaching, for example that for Buddhism there is no special means of worship for them so that the implementation of their worship has not run optimally. In fact, if we look at the purpose of this religious development, it is to strengthen the faith and devotion of female prisoners to Allah SWT so that they can reflect on the consequences of their actions. In addition, religious development activities are also carried out through congregational prayers for Muslims, religious counseling, recitations where the implementer of these activities collaborates with the Ministry of Religion. For Christian prisoners, they are provided with religious guidance in the form of Bible discussion studies, prayer together, while for Buddhists praying together at the monastery with guests from outside the prison.

Another form of personality development undertaken by female prisoners in the Class III Gorontalo Women's Prison is physical development through morning gymnastics and sports. It aims to maintain the health and fitness of inmates and to create a harmonious relationship between prison officers and inmates. This coaching is carried out every morning starting with Morning Gymnastics and followed by sports activities that are favored by inmates.

The mental development of prisoners cannot be separated from the conditions of prisons, although basically prisons are not the best place for prisoners, the implementation of the correctional system as part of development in the field of law in particular and the national development of the nation in general cannot be separated from the influence of the strategic environmental situation and its development from from time to time, both on a national, regional and international scale (Alrianto Tajuddin \& Abung, 2019).

After undergoing a period of personality development, it is continued with independence development, where female prisoners in Class III Gorontalo Women's Prison are offered an activity program, namely Job Development through Job Guidance. As with personality development, this skill development must be followed by all prisoners. From the results of research in the Class III Gorontalo Women's Prison, information was obtained that this form of self-reliance development activity was carried out in collaboration with third parties through the creation of works of art from paper flowers and tote bags, as well as sewing activities. The obstacle in implementing this skill development is that the handicrafts made by inmates have not been marketed properly because there is no cooperation regarding marketing than the handicrafts made by prisoners. Marketing results from the work of female prisoners are only limited to orders from outside the prison.

Female inmates who have served of their criminal term and have good behavior as evidenced by never being registered in register $\mathrm{F}$ are given the opportunity to undergo an assimilation program both inside and outside prison. Based on the results of an interview obtained from one of the correctional officers at the Class III Gorontalo Women's Prison, he stated that the assimilation program at the Gorontalo Women's Prison was carried out only inside the prison by employing them in the office / building, so far there have been no female inmates who run the program. assimilation program outside prison.

After the inmates go through the initial and advanced stages of development, then enter the final stage of coaching. In this final stage of development, female inmates who have served $2 / 3$ of their criminal term begin implementing the integration program. The integration program that will be carried out by female prisoners includes leave before being released, parole and conditional leave which is carried out outside the prison. In order to be able to participate in the integration program, there are several requirements that must be met by prisoners. The purpose of implementing this final stage of development is to integrate female prisoners into community life. The number of female prisoners in the Class III Gorontalo Women's Prison in December 2020 who met the requirements to carry out the integration program was 6 people, with details of all of them undergoing a parole program. 


\subsection{Solutions for Guiding Women Convicts in Class III Gorontalo Prisons}

The implementation of a series of coaching activities carried out at the Class III Gorontalo Women's Prison certainly encountered obstacles. From the data that the author obtained in the field, out of the 51 Correctional Officers in the prison, there were 47 people with high school education, 1 Diploma, 2 Strata 1 people and 1 Strata 2. by female inmates with fairly solid conditions.

With regard to these problems, correctional officers in prisons should have an adequate level of education and intelligence, this can be done by involving correctional officers through training activities that can support the process of coaching activities in prisons. Another thing that needs to be found a solution in the implementation of guidance for female prisoners in the Class III Gorontalo Women's Prison is regarding the supporting facilities and infrastructure in coaching activities. It is necessary to add additional supporting facilities such as places of worship, workshops and so on so that female prisoners can enthusiastically participate in the process of coaching activities in prisons.

Another thing that needs attention from the implementation of coaching is the marketing of handicrafts produced by female prisoners in prison. Due to the Covid condition, the marketing of handicraft products has become very limited, this is due to the limited number of visits that can be made in prisons. For that, it is necessary to cooperate with external parties related to the marketing of handicraft products from female prisoners.

Female inmates who are serving their sentences in prisons are different from male inmates. Female inmates certainly have an emotional level (mental and psychic) where they have to adjust to life in prison and also have to think about the condition of the families left behind, especially those who have children. For this reason, in the implementation of the process of fostering female prisoners, it is necessary to provide mentoring and support programs to support all the positive activities they carry out in prisons. This includes providing psychological counseling services to overcome trauma due to imprisonment which will later help them to be able to prepare themselves to return to their families and communities. In addition, the assimilation program is expected to provide opportunities for female prisoners in Class III A Gorontalo Women's Prison who have met the requirements to be able to carry out assimilation programs outside prison so that they can easily integrate back into society

\section{Conclusion}

The implementation of the form of coaching at the Class III Gorontalo Women's Prison is carried out the same as other inmates, where all inmates are required to follow a whole series of coaching starting from the initial stage of development, advanced stage of development and final stage of coaching. To overcome obstacles in the implementation of prisoner development, synergy is needed between all parties involved starting from prisoners, correctional officers and related agencies to cooperate with each other in terms of implementing the development of female prisoners. In addition, it is necessary to improve and add infrastructure to support coaching activities and to involve officers in prisons through training activities that can support the implementation of coaching. The inmates' handicrafts are also expected to increase marketing through the media, considering the Covid-19 conditions that limit people from being able to interact directly with prisoners in prisons..

\section{Daftar Pustaka}

Alrianto Tajuddin, M., \& Abung, L. (2019). Pembinaan Anak Didik Pemasyarakatan Berorientasi Rehabilitasi Sosial di Lembaga Pemasyarakatan Kelas Ilb Merauke. Al-Adalah:Jurnal Hukum Dan Politik Islam, 4(2), 173-193.

Darmawati. (2019). Aspek Hukum Pemenuhan Hak Atas Pembebasan Bersyarat Bagi Narapidana Korupsi. Jurnal Restorative Justice, 3(2), 108-118.

Harsono, C. I. (1995). Sistem Baru Pembinaan Narapidana. Jakarta: Djambatan.

Nur Dahniar, Safrin Salam, A. S. (2021). Women 's Image on Youtube Content "Sexual Price Survey ": Gender Identity Perspective and Artificial Intelligence. The 3rd Jogjakarta Communication Conference (JCC 2021), 596(Jcc), 125-130. https://doi.org/https://doi.org/10.2991/assehr.k.211121.029

Salam, S. (2019). Rekonstruksi Paradima Filsafat IImu : Studi Kritis Terhadap IImu Hukum Sebagai IImu. 
Ekspose: Jurnal Penelitian Hukum Dan Pendidikan, 18(2), HIm. 885-896. Retrieved from https://books.google.co.id/books?hl=id\&lr=\&id=Rf7_DwAAQBAJ\&oi=fnd\&pg=PA1\&dq=safrin+salam\&ots= dyLnJUHxni\&sig=rD9C2nDYDyi-96XiKcJfGxfoAhw\&redir_esc=y\#v=onepage\&q=safrin salam\&f=false

Zulfa, E. A. (2014). Naskah Akademik Rancangan Undang-Undnag Tentang Perubahan Atas Undang-undang Nomor 12 Tahun 1995 tentang Pemasyarakatan. Jakarta: BPHN. 